NASA Technical Memorandum 101400

\title{
High-Strength Silicon Carbides by Hot Isostatic Pressing
}

\author{
(AASA-TH-101400) HIGE-STBEAGIE SILICON \\ CABBILES BY HCT ISCSTAIIC EEESSING (NASA) \\ 1s $\mathrm{p}$ \\ CSCL $11 \mathrm{C}$ \\ $N 89-13666$ \\ Unclas \\ G3/27 0183239
}

Sunil Dutta

Lewis Research Center

Cleveland, Ohio

Prepared for the

Third International Symposium on Ceramic Materials

and Components for Engines

sponsored by the American Ceramic Society

Las Vegas, Nevada, November 27-30, 1988 


\section{ORIGNAL PAGE IS \\ OF POOR QUALTTY}

higher temperatures $\left(1900\right.$ to $2200^{\circ} \mathrm{C}$ ) for densification. Glass encapsulation softens at this high temperature and, because of its very low viscosity, tends to penetrate into the densifying specimens. Although work has been reported on glass and metal encapsulation for HIPing of silicon nitride preforms, very limited information exists about HIPing of silicon carbide with glass encapsulation. 10,11 Furthermore, information on the HIPing of SiC encapsulated with a refractory metal such as tantalum is virtually nonexistent. This paper reports the properties obtained by the hot isostatic pressing (HIPing) of $\alpha$ - and $\beta-S i C$ compacts encapsulated in tantalum cans, including characterization of strength, microstructure, and toughness.

\section{EXPERIMENTAL PROCEDURES}

Two types of $\alpha-S i C$ and two types of $\beta$-SiC powders were used in this study. Chemical analyses of these powders are shown in Table 1 . The $\alpha$-SiC(I) powder had no premixed sintering aids such as boron and carbon added; however, it did contain 1.74 wt $\%$ excess carbon in the as-received condition. On the other hand, the $\alpha-S i C(I I)^{*}$ powder had premixed sintering aids $(0.6$ wt $\%$ boron and 7.31 wt \% carbon). Both $\beta-S i C(I) * *$ and $\beta$-SiC(II) ${ }^{\star \star *}$ powders had no premixed sintering aids (boron and carbon) but contained small amounts of free carbon (Table 1). Both $\alpha$ - and $\beta-S i C$ compositions were cold formed by a slurry pressing technique.12,13 The dried slurry-pressed compacts $(4.67 \mathrm{~cm}$ in diameter by $0.6 \mathrm{~cm}$ thick) were wrapped with graphite foil, coated with boron nitride, and then placed in tantalum cans. The tantalum cans were outgassed for 6 to $8 \mathrm{hr}$ at $1100{ }^{\circ} \mathrm{C}$ and then vacuum sealed. After a thorough leak check the cans were placed in a hot isostatic pressing furnace. An initial gas pressure of $14 \mathrm{MPa}$ (2000 psi) was applied; then both temperature and pressure were increased simultaneously until the desired values were reached. The cans were HIPed at temperatures between 1850 and $2100{ }^{\circ} \mathrm{C}$ for 30 to $120 \mathrm{~min}$ under $138 \mathrm{MPa}$ argon gas pressure. HIPed specimens were machined into test bars $(2.54$ by 0.64 by $0.32 \mathrm{~cm})$, and the surfaces were ground with a 400 -grit fine diamond wheel to a final surface finish of 8 rms. Density was measured by the water immersion method. Microstructural characterization was made by optical and electron microscopy. Flexural strength tests were conducted by four-point bending, with $0.95-\mathrm{cm}$ inner and $1.87-\mathrm{cm}$ outer spans. Testing was conducted at room temperature with a crosshead speed of $0.05 \mathrm{~cm} / \mathrm{min}$. Weibull modulus values were generated from the strength data, and the results were analyzed by using $F$ - and t-tests. Fracture surfaces of selected test bars were examined by scanning electron microscopy to identify the strength-controlling critical flaws. Fracture toughness was determined by the Vicker's hardness indentation technique with a 2500-g load.

\footnotetext{
*H.C. Starck, West Berlin, FRG.

* Ibiden Co. Ltd., Ogaki, Japan.

*** Superior Graphite Co. Ltd., Chicago, Illinois.
} 
RESULTS AND DISCUSSION

Hot-Isostatic-Pressed $\alpha$-SiC

The densification behaviors of HIPed $\alpha-\operatorname{SiC}(I)$ and $\alpha$-SiC(II) are shown in Fig. 1. The $\alpha$-SiC(I) exhibited sluggish densification behavior, and this resulted in lower final densities at all temperatures from 1800 to $2100{ }^{\circ} \mathrm{C}$.

The maximum density for this material (97 percent of theoretical) was achieved at $2100{ }^{\circ} \mathrm{C}$ (Fig. 1). By contrast, only $1900^{\circ} \mathrm{C}$ was required to sinter $\alpha$-SiC(II) powder (containing boron and carbon sintering aids) to a final density of 98 percent of theoretical. No further increase in final density was observed with further increases in temperature from 1900 to $2100{ }^{\circ} \mathrm{C}$. The results suggest that, although it is difficult, $\alpha-S i C$ (I) powder can be HIPed to high final density without any sintering aids. The results are in good agreement with Homma et al. ${ }^{10}$ and Larker et al. 11, who obtained high final density ( 96 percent of theoretical) in HIPed a-SiC without any sintering aids.

Microstructural characterization was made on polished and etched samples. Figure 2 shows photomicrographs of polished and etched $\alpha$-SiC(I) HIPed at 1900 and $2000{ }^{\circ} \mathrm{C}$ for 30,60 , and $120 \mathrm{~min}$. The microstructure essentially consisted of single-phase $\alpha-S i C$ matrix with residual porosities (determined from density measurements) varying from 14 percent for the $1900{ }^{\circ} \mathrm{C}$, 30-min-HIPed specimens, to 5 percent for the $2000{ }^{\circ} \mathrm{C}, 120$-min-HIPed specimens. The $\alpha-S i C$ grains were difficult to etch, and therefore the overall microstructure could not be resolved by optical microscopy. By contrast, clear microstructures with distinct grain boundaries were achieved in $\alpha$-SiC(II) specimens (Fig. 3). Very little grain growth was observed in $\alpha$-SiC materials HIPed between $1900{ }^{\circ} \mathrm{C}$ for $30 \mathrm{~min}$ and $2000{ }^{\circ} \mathrm{C}$ for $120 \mathrm{~min}$ (Figs. 2 and 3 ). The high-density a-SiC produced by HIPing exhibited an ultra-fine-grained microstructure with grain size varying from 0.2 to $5.0 \mu \mathrm{m}$. Grain morphology was equiaxed in both $\alpha$-SiC materials.

The room-temperature flexural strengths of of $\alpha$-SiC(I) HIPed at 1900 and $2000{ }^{\circ} \mathrm{C}$ for various times are shown in Fig. 4. Average strengths $=1$ standard deviation (12 test bars) were $368 \pm 51 \mathrm{MPa}, 444 \pm 51 \mathrm{MPa}$, and $488 \pm 40 \mathrm{MPa}$ for specimens HIPed at $1900{ }^{\circ} \mathrm{C}$ for 30,60 , and $120 \mathrm{~min}$, respectively. Final densities were 86,88 , and 91.5 percent of theoretical, respectively. Statistical analys is by the F-test (comparison of variances) indicated no significant differences among the variances. Student's t-test indicated that at the 95 percent confidence level there was no statistically significant difference in the room-temperature strength. At the higher HIPing temperature $\left(2000^{\circ} \mathrm{C}\right)$, average strengths were $551 \pm 98 \mathrm{MPa}, 574 \pm 73 \mathrm{MPa}$, and $619 \pm 63 \mathrm{MPa}$ for specimens having densities of $91.6,92.7$, and 95 percent of theoretical and HIPed for 30, 60, and 120 min, respectively. The $F$-test indicated no significant difference among the variances. Student's t-test at the 95 percent confidence level indicated no significant strength difference between specimens sintered for $30 \mathrm{~min}$ versus $60 \mathrm{~min}$ and for $60 \mathrm{~min}$ versus $120 \mathrm{~min}$, but a significant difference in strength between specimens sintered for $30 \mathrm{~min}$ versus $120 \mathrm{~min}$. Student's t-test also indicated that the room-temperature strengths of materials sintered at $2000{ }^{\circ} \mathrm{C}$ were statistically higher than $1900{ }^{\circ} \mathrm{C}$ strength at the 95 percent confidence level. The highest strength, 
$619 \mathrm{MPa}$, obtained in HIPed $\alpha$-SiC(I) was higher than the strength ( $540 \mathrm{MPa}$ ) reported by Larker, et al. 11 for HIPed $\alpha-S i C$ material. The results suggest that $\alpha-S i C(I)$ containing no sintering aids (boron and carbon) can exhibit very high flexural strength when HIPed to high final density.

A density effect on strength or in other words a porosity effect on strength was observed in HIPed $\alpha$-SiC(I) specimens. The strength of porous ceramics decreased nearly exponentially with increases in porosity. Various specific analytical relationships have been suggested for the effect of porosity on strength. Ryshkewitch 14 has shown that porosity and strength are generally empirically related by

$$
\sigma=\sigma_{0} \exp (-n P)
$$

where

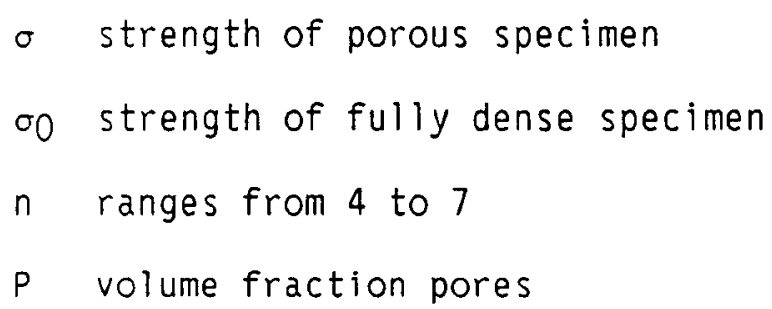

From this relation the volume fraction pores as a function of strength in HIPed $\alpha$-SiC(I) was determined as shown in Fig. 5 . Regression analysis yielded the following equation:

$$
\sigma=845 \exp (-5.64 P)
$$

Note that the constant in the exponent $(n=5.64)$ falls at the approximate midpoint between 4 and 7 and is in good agreement with Ryshkewitch's relation and that at zero porosity the strength would be $845 \mathrm{MPa}$.

The flexural strength data of $\alpha$-SiC(II) (containing boron and carbon) are shown in Fig. 6. The average strengths ( 12 test bars) were $596 \pm 59,614 \pm 61$, and $625 \pm 65 \mathrm{MPa}$ at $1900{ }^{\circ} \mathrm{C}$ and $650 \pm 58,620 \pm 79$, and $564 \pm 78 \mathrm{MPa}$ at $2000^{\circ} \mathrm{C}$ for sintering times of 30,60 , and $120 \mathrm{~min}$, respectively. Statistical analyses such as the F-test and Student's t-test indicated no significant differences in strengths and variances. These strengths were statistically higher than the strengths found in $\alpha$-SiC(I) specimens HIPed at 1900 and $2000{ }^{\circ} \mathrm{C}$. However, at a final density level of 95 percent of theoretical for the $\alpha-\operatorname{SiC}(I)$, the strength (619 MPa) of $\alpha$-SiC(I) was statistically comparable with the strengths of $\alpha$-SIC(II). The results suggest that $\alpha-\operatorname{SiC}(I)$ (containing no sintering aids) can exhibit high flexural strength comparable to $\alpha$-SiC(II) material when HIPed to the same high final density.

The data clearly indicated no systematic correlation between strength and Weibull modulus. Although a significant improvement in strength was achieved in hot isostatically pressed $\alpha$-SiC over the sintered $\alpha-S i C$ strength of $428 \mathrm{MPa}$, 15 no improvement in Weibull modulus was obtained. For materials HIPed at 1900 to $2000{ }^{\circ} \mathrm{C}$, the Weibull modulus was estimated to be 8 to 14 for $\alpha$-SiC(I) and 8 to 13 for $\alpha$-SiC(II) The Weibull modulus for pressureless sintered $\alpha-\operatorname{SiC}$ ranges from 8 to $12.15,16$ Process-related 
critical flaws, such as large isolated pores and shrinkage cracks, typical of sintered materials 5 were not observed in HIPed materials. Typical fracture initiation sites were found to be surface related in HIPed $\alpha$-SiC.

These are shown in Fig. 7.

Hot-Isostatic-Pressed $\beta-$ SiC

As-received $\beta$-SiC(I) and $\beta$-SiC(II) powders were used. The chemical analysis of these powders are shown in Table 1. Neither $\beta-S i C$ (I) nor $\beta-S i C$ (II) powders had premixed sintering aids. The $\beta$-SiC(I) powder was slurry pressed with 3 and 4 wt $\%$ carbon and 0.6 wt $\%$ boron; the $\beta$-SiC(II) powder was slurry pressed only with 3 wt $\%$ carbon and 0.6 wt $\%$ boron. On the basis of a preliminary HIPing study, a temperature of $1900{ }^{\circ} \mathrm{C}$ for $60 \mathrm{~min}$ was chosen for HIPing $B-S i C$ compositions to near-theoretical density (97 percent). Typical microstructures of HIPed $\alpha$-SiC(II) and $\beta$-SiC(I) are shown in Fig. 8. The submicrometer $\beta$-SiC grain size $(<1.00 \mu \mathrm{m})$ was much finer than the typical microstructure of HIPed $\alpha$-SiC (Fig. 3 ). Furthermore, the $\beta-$ to- $\alpha$ phase transformation typical of high-temperature sintered $\beta-S i C$ microstructure ( $F i g .9$ ) was not observed in the "low"temperature-HIPed $\beta$-SiC (Fig. 8 ). The grain morphology was completely equiaxed and uniform.

The room-temperature flexural strengths of $\beta-S i C(I)$ and $\beta-S i C(I I)$ HIPed at $1900{ }^{\circ} \mathrm{C}$ for $60 \mathrm{~min}$ are shown in $\mathrm{Fig}$. 10. Average strengths (22 test bars) were $659 \pm 79$ and $673 \pm 66 \mathrm{MPa}$ for $B-S i C(I)$ specimens with 3 and 4 wt \% carbon, respectively. The strength of $B$-SiC(II) specimens with 3 wt \% carbon was $645 \pm 100 \mathrm{MPa}$. Statistical analyses by the F-test (comparison of variances) and Student's t-test indicated no significant differences in variance or in room-temperature strength between $\beta-S i C$ (I) and $\beta-S i C$ (II) specimens. The results indicated that both commercially available $B-S i C$ powders, when HIPed to high final density, yield material similar in strength to HIPed $\alpha-S i C$. The strength data for both $\beta-S i C(I)$ and $\beta-S i C(I I)$ were compared with those for HIPed $\beta$-SiC(II) specimens (Fig. 11). In general, no statistically significant difference in strength was found. The Weibull modulus was estimated to the 9.5 to 11 for $\beta$-SiC(I) and 7 for $\beta-S i C$ (II) compositions, about the same as for $\alpha$-SiC compositions. The strength-controlling flaws in HIPed $B-S i C$ were generally surface related and similar to those observed in HIPed $\alpha-S i C$. These are shown in Fig. 12. The highest-strength samples broke into numerous pieces, and specific failure origins could not be identified.

Fracture toughness $K_{1 C}$ was determined by direct crack measurements of Vicker's indentations in both $\alpha$ - and $\beta$-SiC HIPed to a final density of 97 percent of theoretical. Fracture toughness $K_{1 C}$ was estimated by using the relation derived by Evans, 17 which is as follows:

where

$$
\frac{\log K_{l c}}{H a^{1 / 2}} \frac{H^{2 / 5}}{E}=16.32 x^{5}-24.97 x^{4}+11.23 x^{3}-2.02 x^{2}-0.34-1.59
$$

Kic fracture toughness 


\title{
ORIGNAL PAGR IS \\ Of́ POOR QUACTE
}

\author{
H hardness \\ a indentation radius \\ E Young's modulus \\ $X \log (c / a)$ \\ c crack length
}

Fracture toughness values determined by this relationship gave results closest to existing $K_{1 C}$ datal6 determined by chevron notch and controlled-surface flaw techniques. The $K_{i C}$ values ranged from 3.6 to $4.0 \mathrm{MPa} \mathrm{m} 1 / 2$ for HIPed $\alpha-S i C$ and from 3.7 to $4.1 \mathrm{MPa} \mathrm{m} \mathrm{m}^{1 / 2}$ for HIPed $B-S i C$. Statistical analyses such as the $F$-test indicated no significant difference in variances, and Student's t-test indicated no significant difference in $K_{1 C}$ between HIPed $\alpha$ - and $\beta-S i C$ specimens. However, $K_{1 C}$ values for HIPed $\alpha$ - and $\beta$-SiC were higher than those observed in pressureless sintered $\alpha-\operatorname{SiC}\left(3\right.$ to $3.6 \mathrm{MPa} \mathrm{m}^{1 / 2}$ ). For HIPed $\alpha$ - and $\beta-\mathrm{SiC}$ and pressureless sintered $\alpha-S i C$, the $F$-test indicated no significant differences among the variances, but Student's t-test indicated statistically significant differences in $K_{1} C$ values. Although statistically significant differences were observed, the improvement was not of sufficient magnitude to be of practical significance. Higher $K_{1 C}$ values were related to smaller grain size in HIPed $\alpha$ - and $\beta$-SiC materials. 18,19

\section{CONCLUDING REMARKS}

In this study both $\alpha$ - and $\beta$-SiC compositions, with and without sintering aids (boron and carbon), were HIPed to near-theoretical density (97 to 98 percent of theoretical). The HIPed materials had ultrafine grain size $(0.3$ to $5 \mu \mathrm{m}$ for $\alpha-S i C$ and $<1.00 \mu \mathrm{m}$ for $\beta-S i C$ compositions). Both materials exhibited high average flexural strength. Furthermore, $\alpha$-SiC bodies without any sintering aids, when HIPed to high final density, exhibited very high strength. Also, higher fracture toughness was obtained in HIPed $\alpha$ - and $\beta-S i C$ than in pressureless sintered $\alpha$-SiC from an earlier study. The strength-controlling flaws, such as large voids and shrinkage cracks, typical of sintered SiC materials, were not observed in HIPed SiC. However, no improvement in Weibull modulus was observed over sintered SiC materials. Thus it is clear that although significant improvement has been made in strength via improved microstructure and minimization of processing flaws by HIPing, improvements in reliability and practically significant improvements in fracture toughness were not achieved. Thus other approaches such as compositing are needed to advance significantly beyond the current state of the art. 


\section{REFERENCES}

1. S. Prochazka, "Sintering of Silicon Carbide," pp. 239-252 in Ceramics for High-Performance Applications, Edited by J.J. Burke, A.E. Gorum, and R.N. Katz, Brook Hill Publishing Co., Chestnut Hill, MA, 1974.

2. J.A. Coppola, H.A. Lawler, and C.H. McMurtry, "Silicon Carbide Powder and Sintered Materials From the Powder," U.S. Patent 4,123,286, 1978.

3. W. Bocker, H. Landfermann, and H. Hausner, "Sintering of Alpha Silicon Carbide With Additions of Aluminum," Powder Met. Int., 11 [2] 83-85 (1979).

4. M. Omori and H. Takei, "Pressureless Sintering of SiC," J.Am. Ceram. Soc., $65[6]$, C92 (1982).

5. S. Dutta, "Sinterability, Strength, and Oxidation of Alpha Silicon Carbide Powders," J. Mater. Sci., 19 [4] 1307-1313 (1984).

6. S. Dutta, "Densification and Properties of $\alpha$-Silicon Carbide," J. Am. Ceram. Soc., 68 [10] C269-C270 (1985).

7. K. Negita, "Effective Sintering Aids for Silicon Carbide Ceramics: Reactivities of Silicon Carbide With Various Additives," J. Am. Ceram. Soc., 69 [12] C308 (1986).

8. H.T. Larker, J. Adlerborn, and H. Bohman, "Fabrication of Dense Silicon Nitride Parts by Hot Isostatic Pressing," SAE Paper 770335, 1977.

9. H.T. Larker, "HIP Silicon Nitride," pp. 18-1 to 18-4 in Ceramics for Turbine Engine Applications, AGARD CP-276, AGARD, Neuilly-Sur-Seine, France, 1979.

10. K. Homma, F. Yamamoto, and H. Okada, "HIP Sintering of Silicon Carbide Without Additives," J. Ceram. Soc. Jpn. (Yogyo kyokai-Shi), 95 [2] 223-228 (1987).

11. H.T. Larker, L. Hermansson, and J. Adlerborn, "Hot Isostatic Pressing and Its Applicability to Silicon Carbide and Boron Carbide," Ind. Ceram., 8 [1] 17-20 (1988).

12. M.R. Freedman and M.L. Millard, "Improved Consolidation of Silicon Carbide," Ceram. Eng. Sci. Proc., 8 [7-8] 884-892 (1986).

13. J.B. Hurst and S. Dutta, "Simple Processing Method for High-Strength Silicon Carbide," J. Amer. Ceram. Soc., 70 [11] C303-C308 (1987).

14. E. Ryshkewitch, "Compression Strength of Porous Sintered Alumina and Zirconia," J.Am. Ceram. Soc., 36 [2] 65-68 (1953).

15. S. Dutta, "Improved Processing of $\alpha-S i C, "$ Adv. Ceram. Mater., 3 [3] 257-262 (1988). 
16. R.K. Govila, "High-Temperature Strength Characterization of Sintered Alpha Silicon Carbide," AMMRC TR-82-51, 1982. (Avail. NTIS, AD-A121437.)

17. A.G. Evans, "Fracture Toughness: The Role of Indentation Techniques," pp. 112-135 in Fracture Mechanics Applied to Brittle Materials, ASTM-STP-678, edited by S.W. Freiman, American Society for Testing Materials, Philadelphia, 1979.

18. B.D. Kruse and H. Hausner, "Fracture Toughness of Sintered Alpha Silicon Carbide," pp. 453-459 in Science of Ceramics, Vol. 11, edited by H. Hausner; Deutsche Keramische Gesellschaft, Germany, 1981.

19. C.M. Dannels and S. Dutta, "The Effect of Processing on Fracture Toughness of Silicon Carbide as Determined by Vicker's Indentations," J. Amer. Ceram. Soc., submitted for publication.

Table 1. - Analysis of As-received $\alpha-S i C$ and $\beta-S i C$ Powders

\begin{tabular}{|c|c|c|c|c|}
\hline \multirow[t]{2}{*}{ Element } & $\alpha-\operatorname{SiC}(I)$ & $\alpha-\operatorname{SiC}(I I)$ & $\beta-\operatorname{SiC}(I)^{\alpha}$ & $\beta-\operatorname{SiC}(\text { II })^{b}$ \\
\hline & \multicolumn{4}{|c|}{ Content, ppm } \\
\hline $\begin{array}{l}\mathrm{Al} \\
\mathrm{Cr} \\
\mathrm{Fe} \\
\mathrm{Ti} \\
\mathrm{V} \\
\mathrm{B} \\
\text { Free C }\end{array}$ & $\begin{array}{l}50 \\
70 \\
10 \\
20 \\
20 \\
\\
c_{1} .74\end{array}$ & $\begin{array}{l}140 \\
40 \\
10 \\
30 \\
20 \\
c_{0.60} \\
c_{7.31}\end{array}$ & \begin{tabular}{c}
300 \\
Trace \\
700 \\
\hdashline \\
$c_{0} 0.65$
\end{tabular} & $\begin{array}{l}100 \\
20 \\
200 \\
- \\
- \\
- \\
c<2.0\end{array}$ \\
\hline $\begin{array}{l}\text { Surface } \\
\operatorname{area}(B E T), \\
m^{2} / g\end{array}$ & 31.47 & 22 & 19.8 & 10 \\
\hline
\end{tabular}

IIbiden Co. Ltd., Ogaki, Japan.

bsuperior Graphite Co. Ltd., Chicago, Illinois.

CUnit is weight percent. 


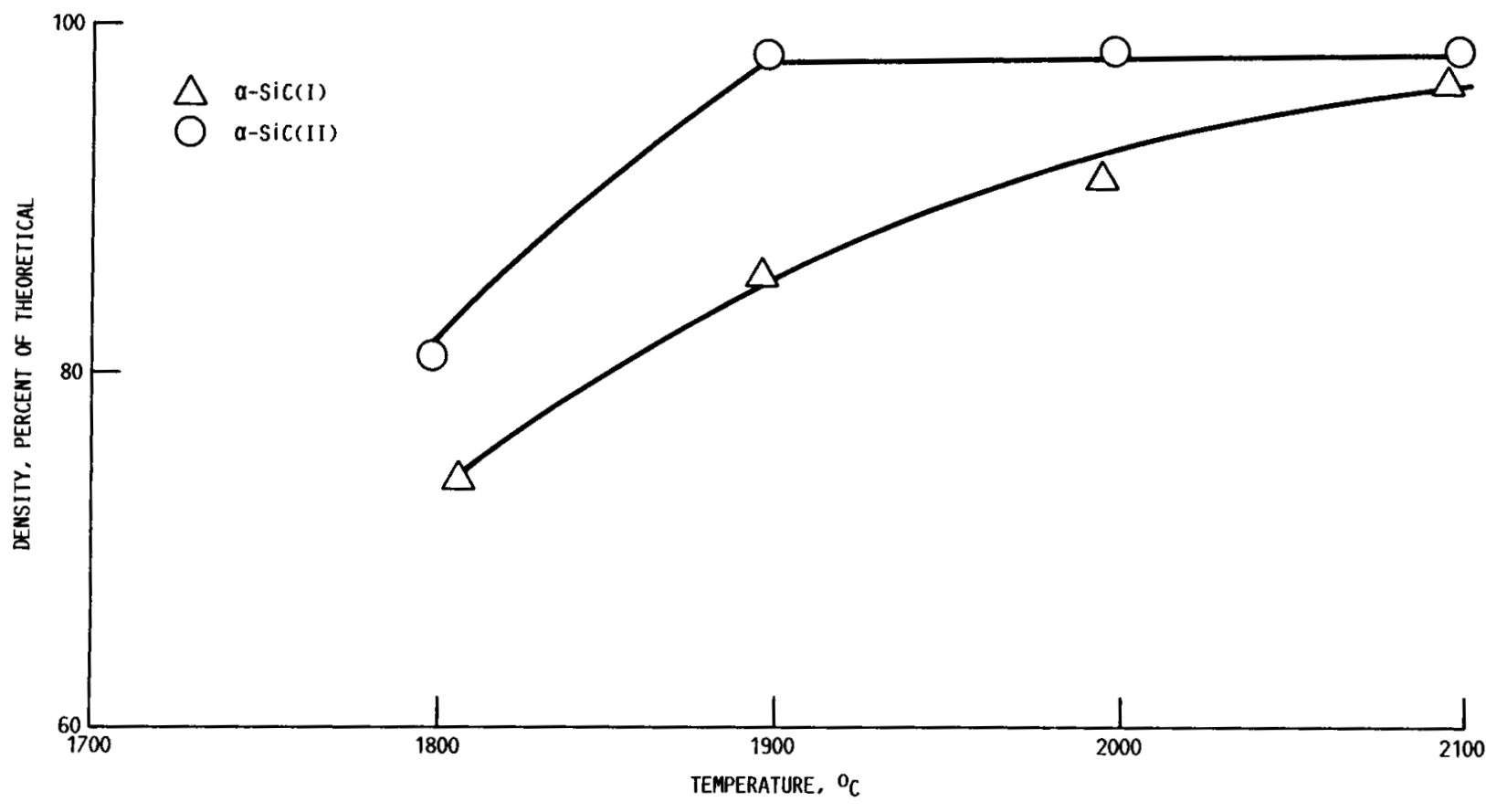

FIGURE 1. - RELATIVE DENSITY OF Q - SiC POHDERS HIPEd FOR 30 MIN AT DIFFERENT IEMPERATURES. 

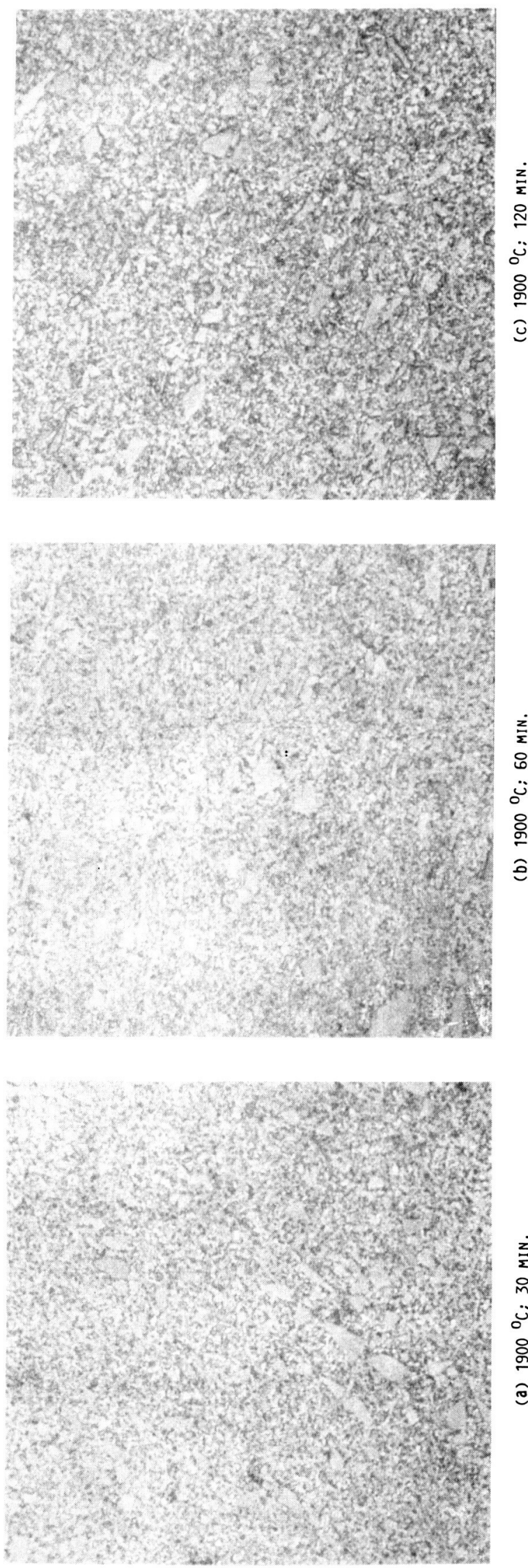
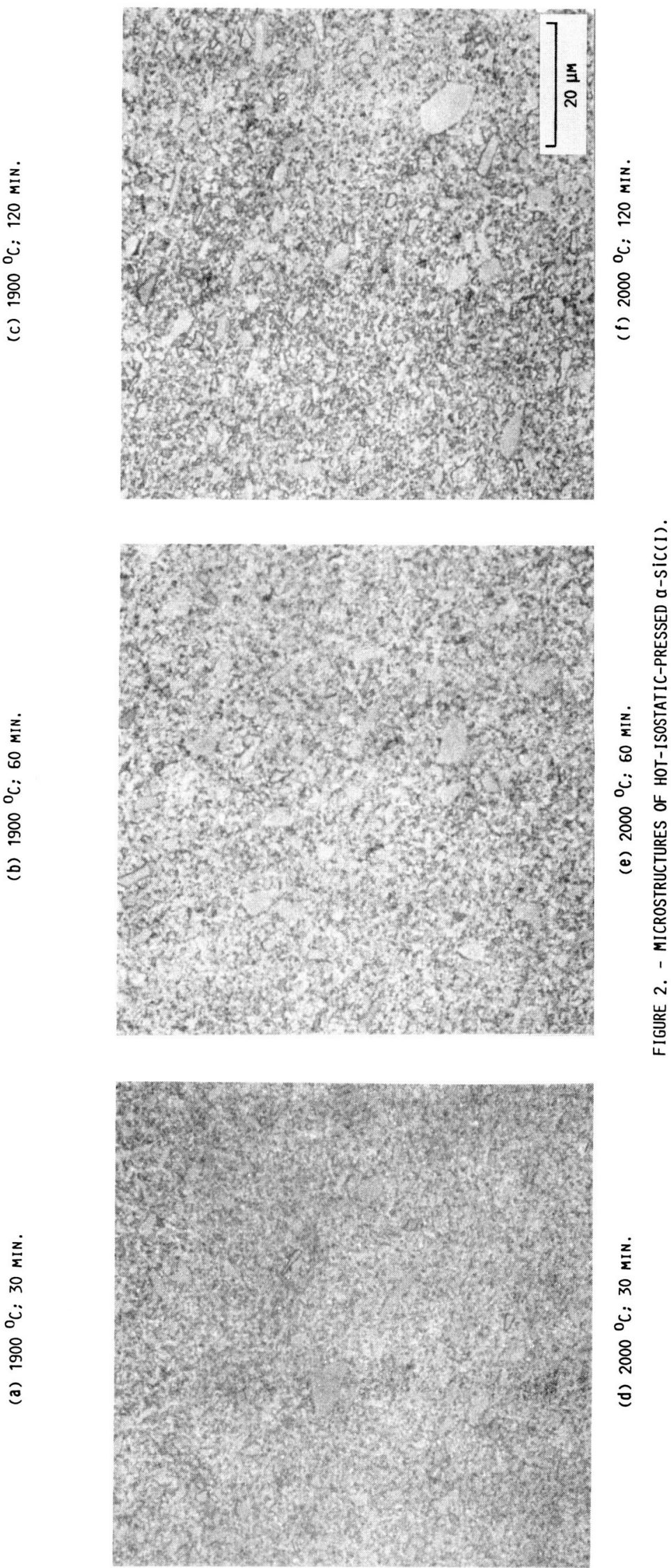


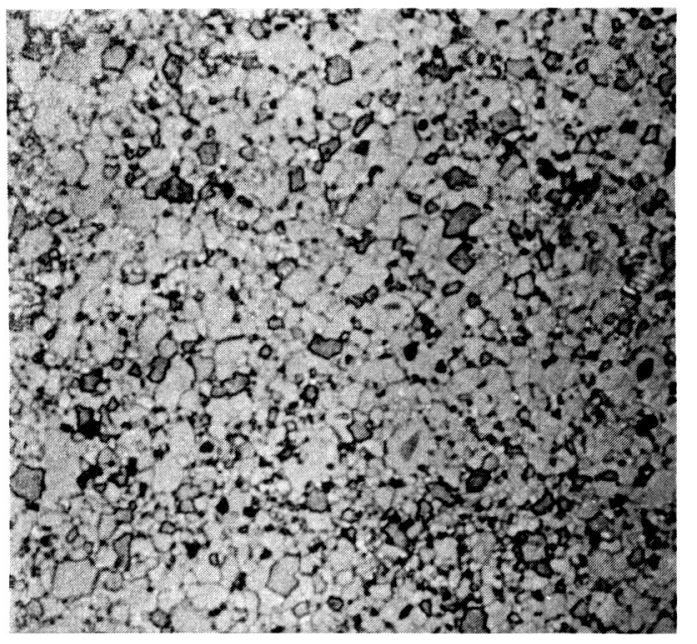

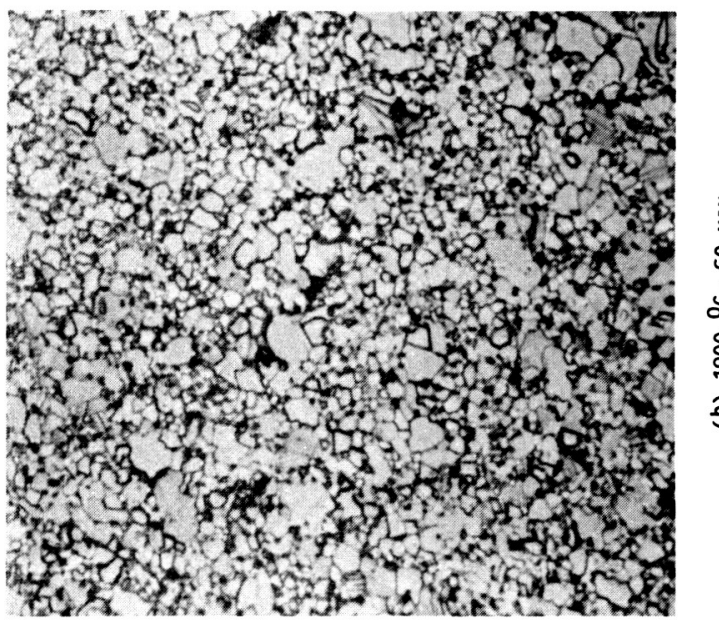

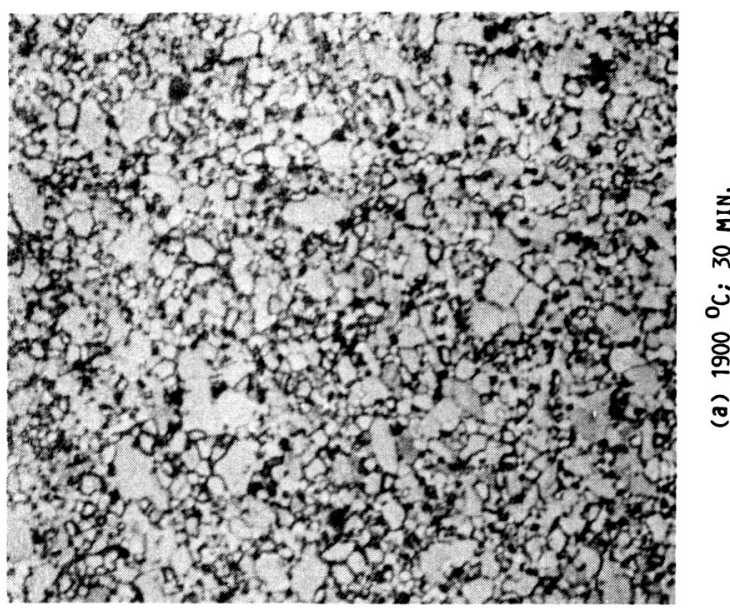

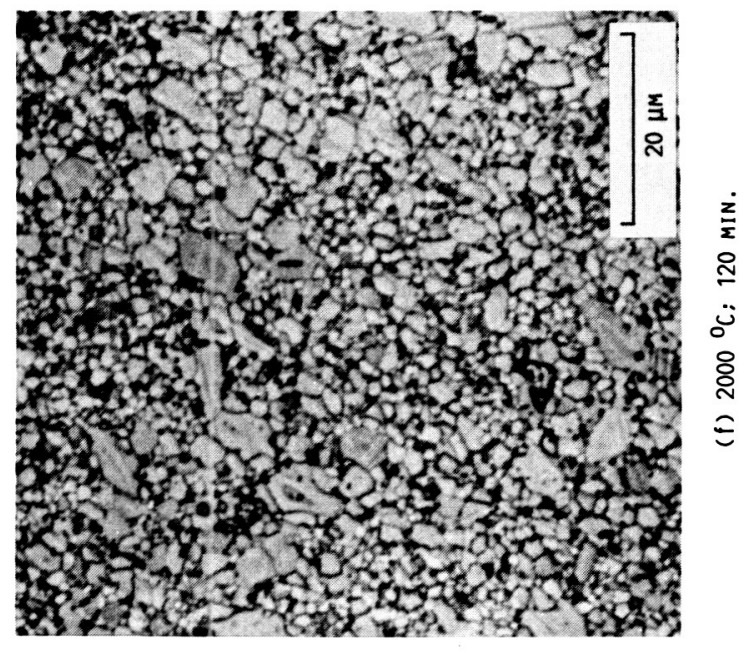
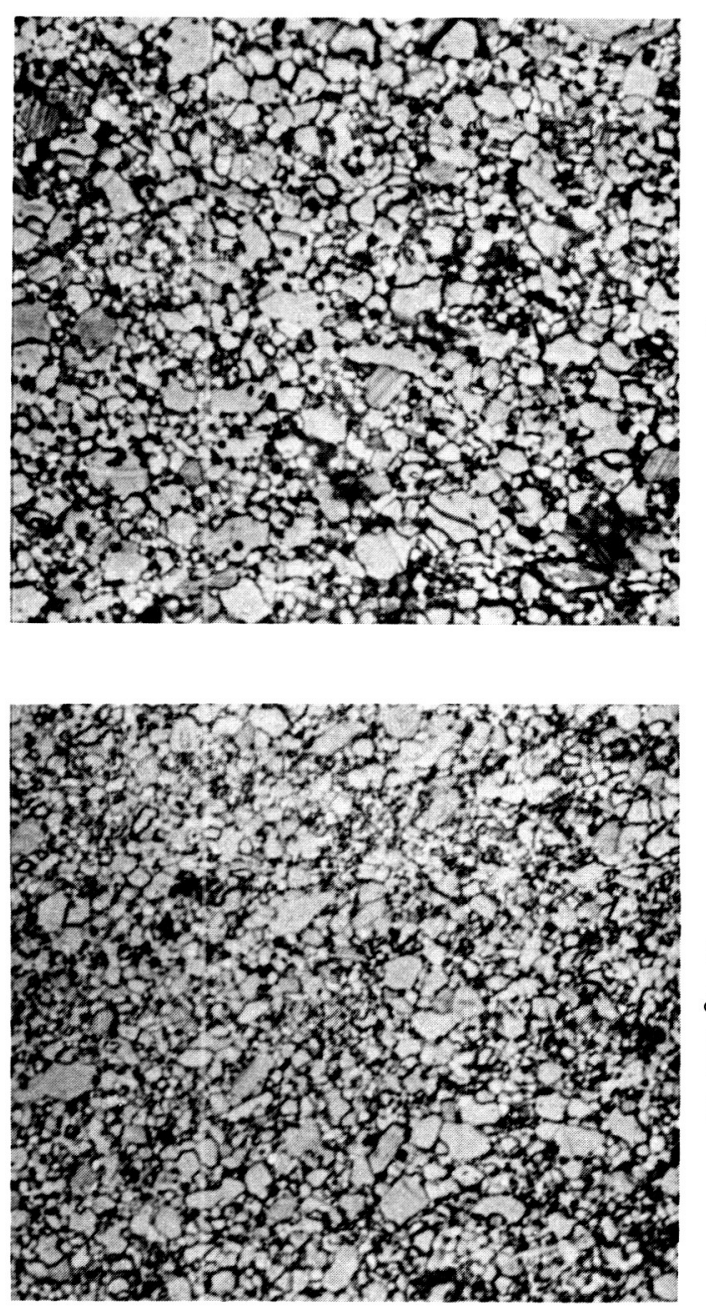

ORIGINAT PAGE IS
OR FOOR QUAJWX 


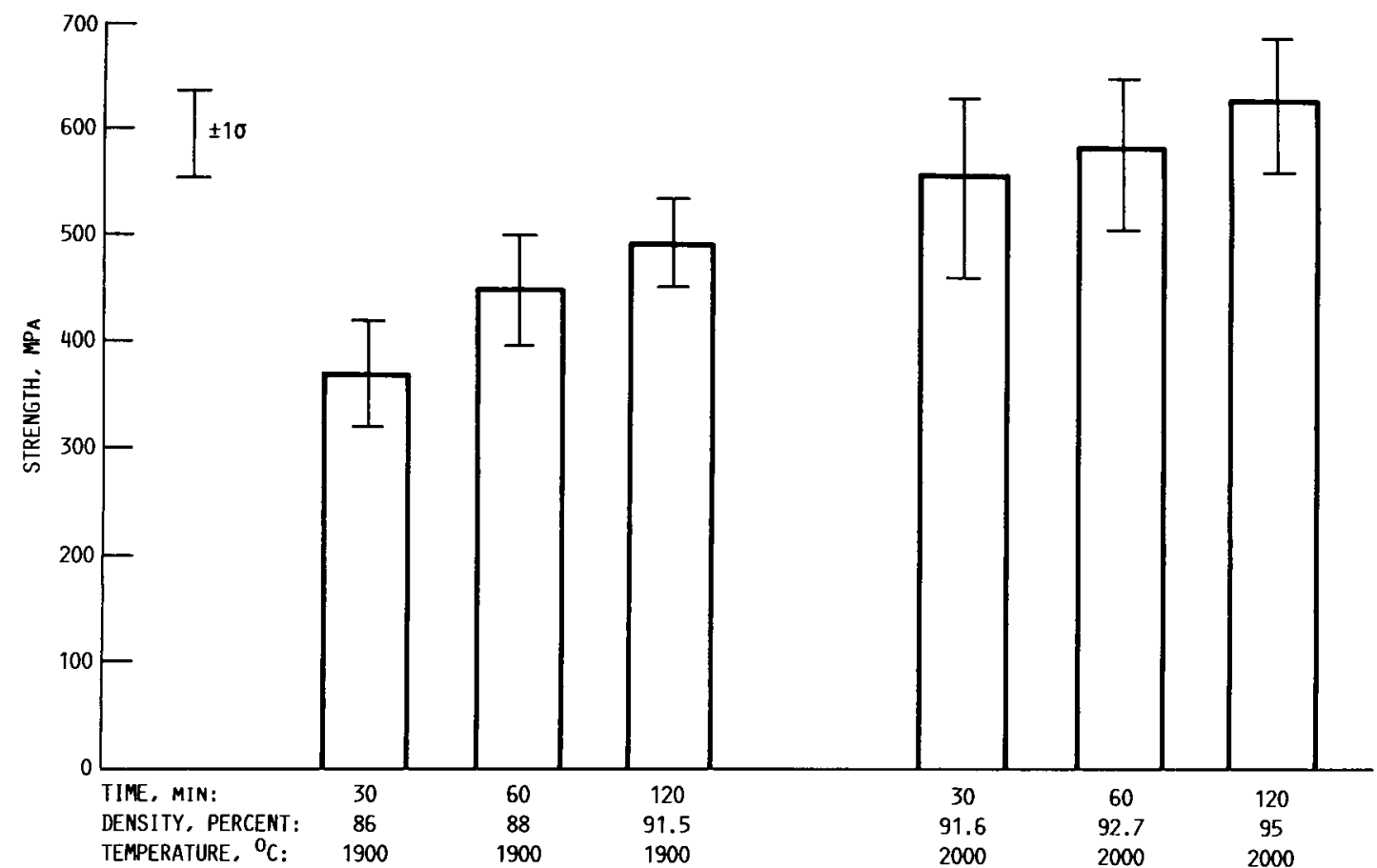

FIGURE 4. - ROOM-TEMPERATURE FLEXURAL STRENGTH OF $\alpha$-SiC(I) HIPED AT DIFFERENT TEMPERATURES AND TIMES.

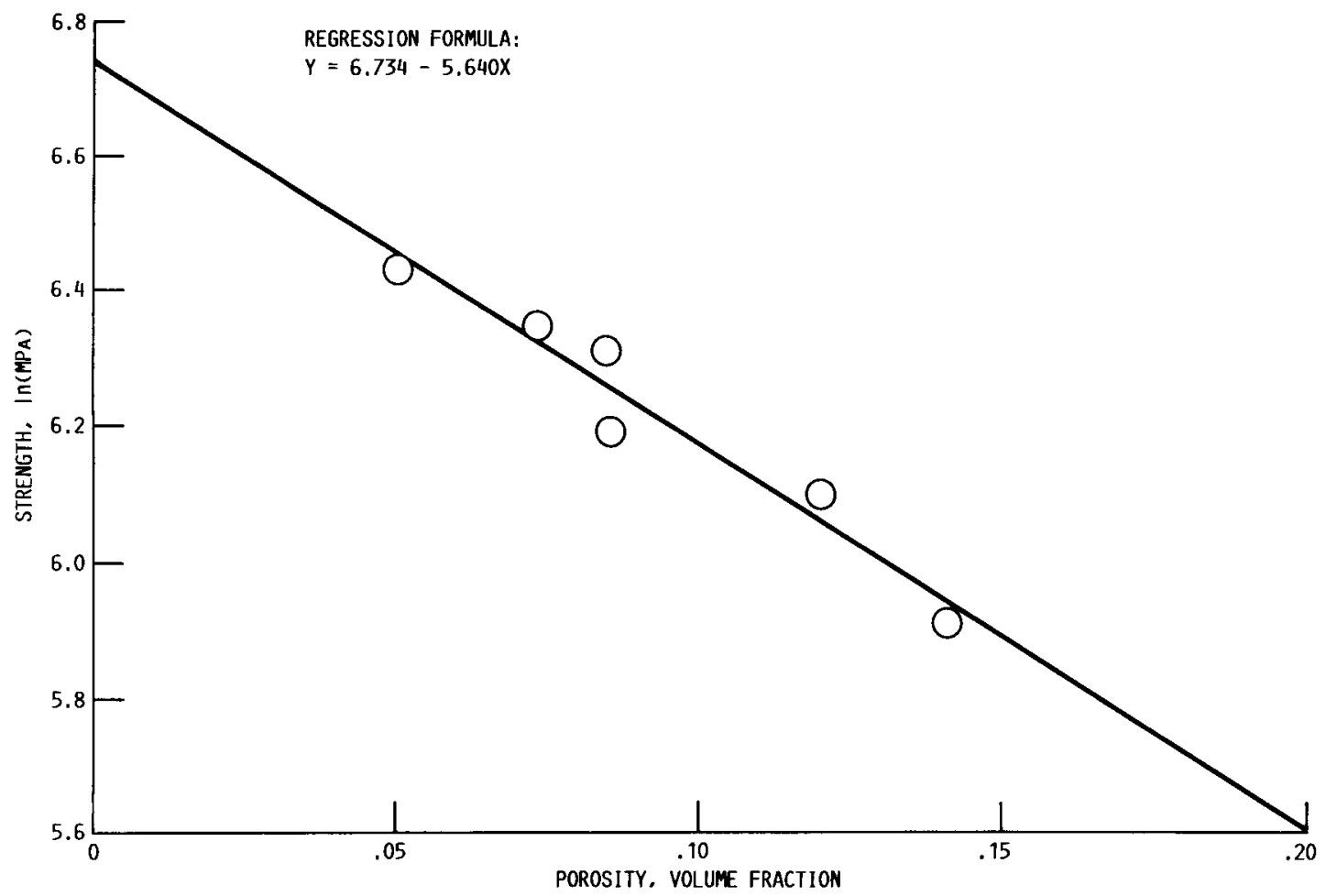

FIGURE 5. - ROOM-TEMPERATURE FLEXURAL STRENGTH OF HIPED a-SIC(1) AS FUNCTION OF POROSITY. 


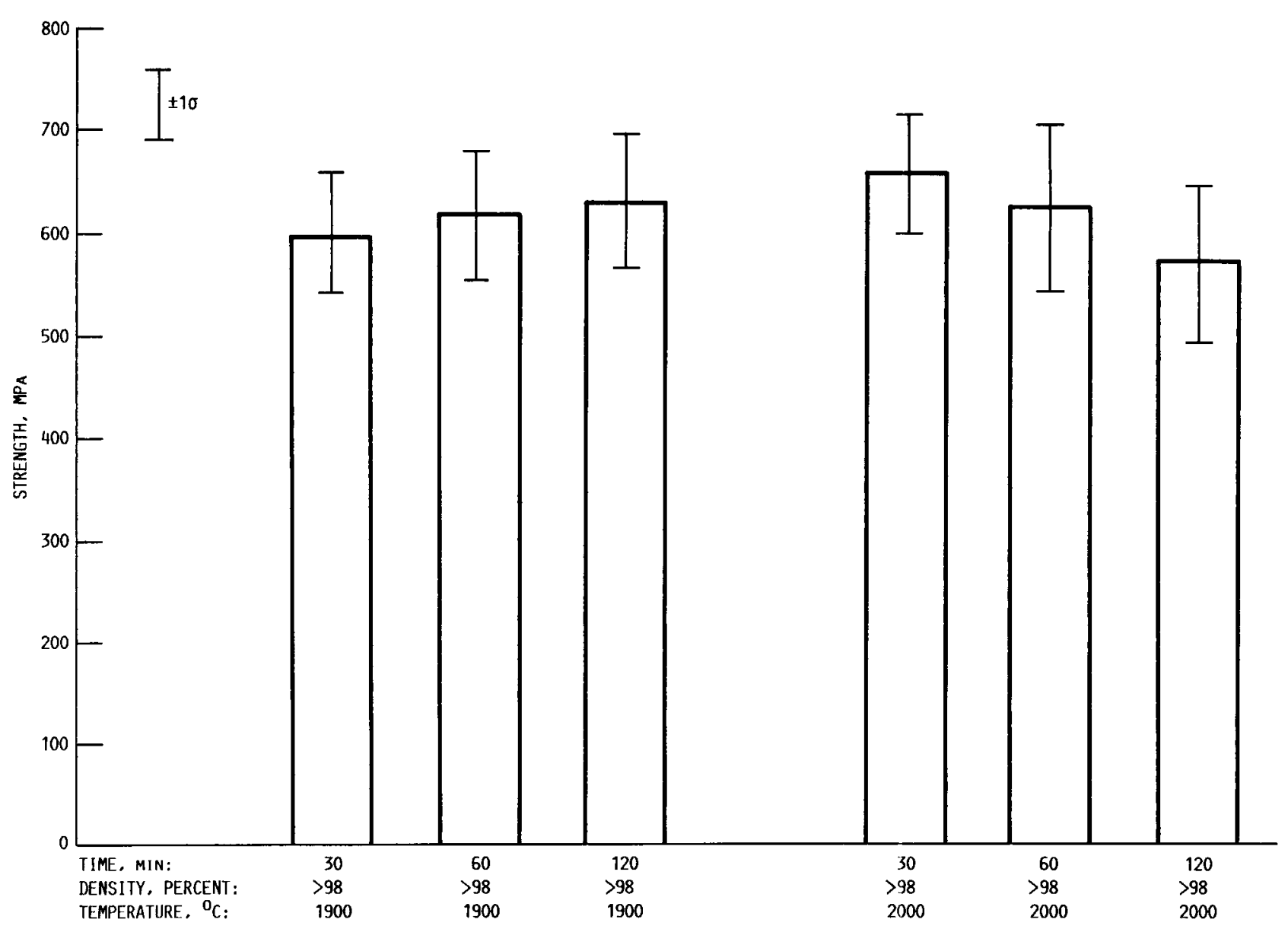

FIGURE 6. - ROOM-TEMPERATURE FLEXURAL STRENGTH OF $\alpha$-SiC(II) HIPED AT DIFFERENT TEMPERATURES AND TIMES. 


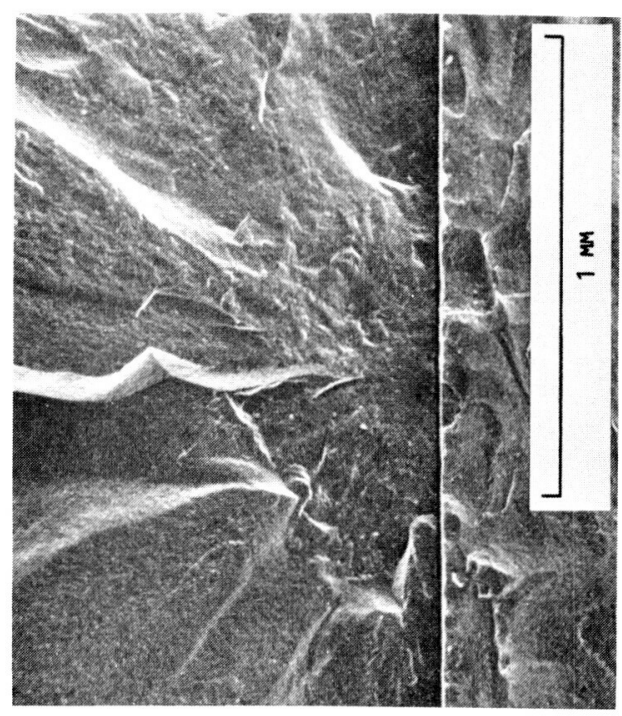

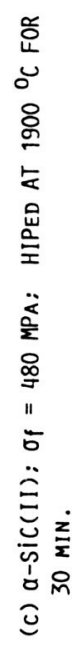

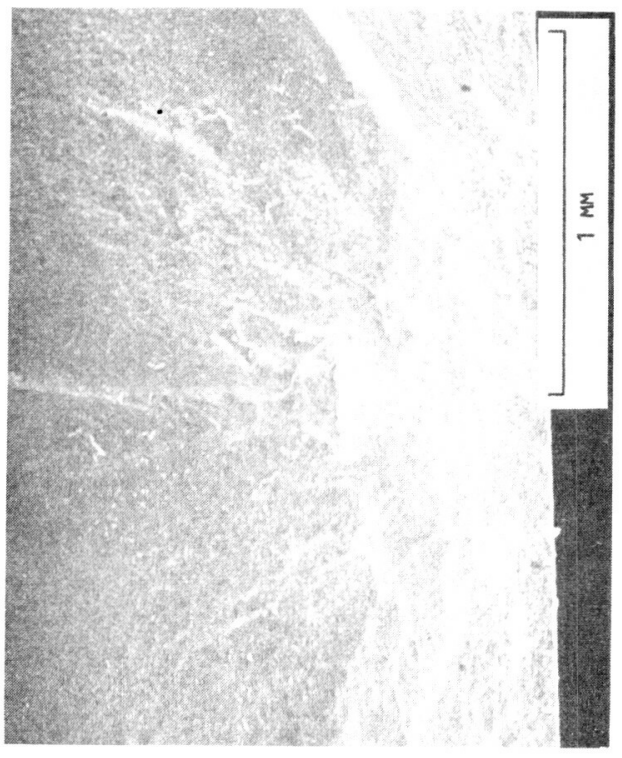

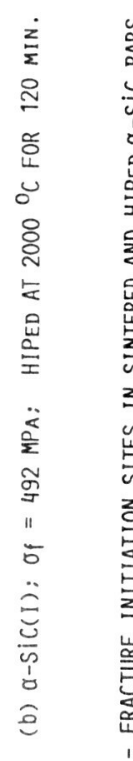
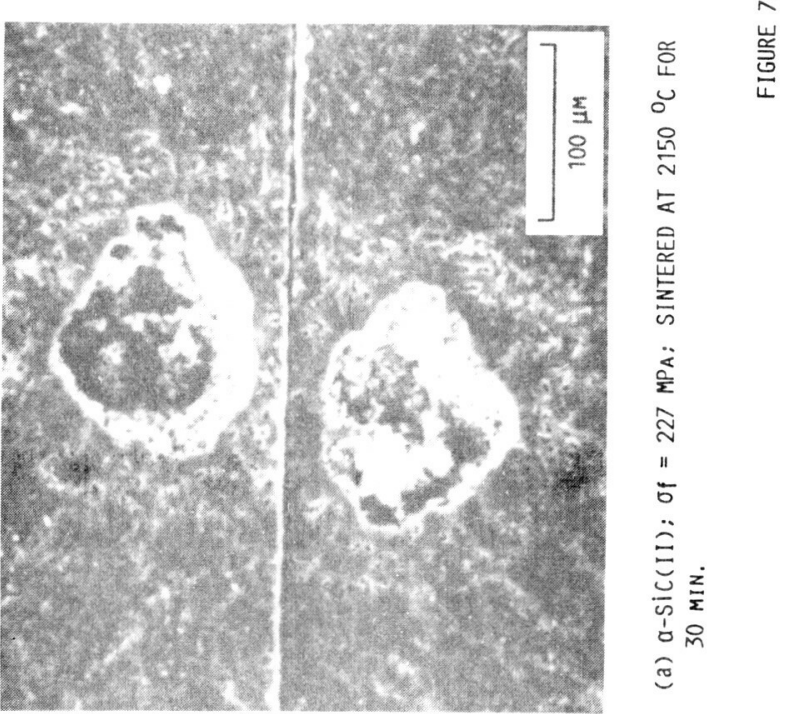
ORITIAT PRCE
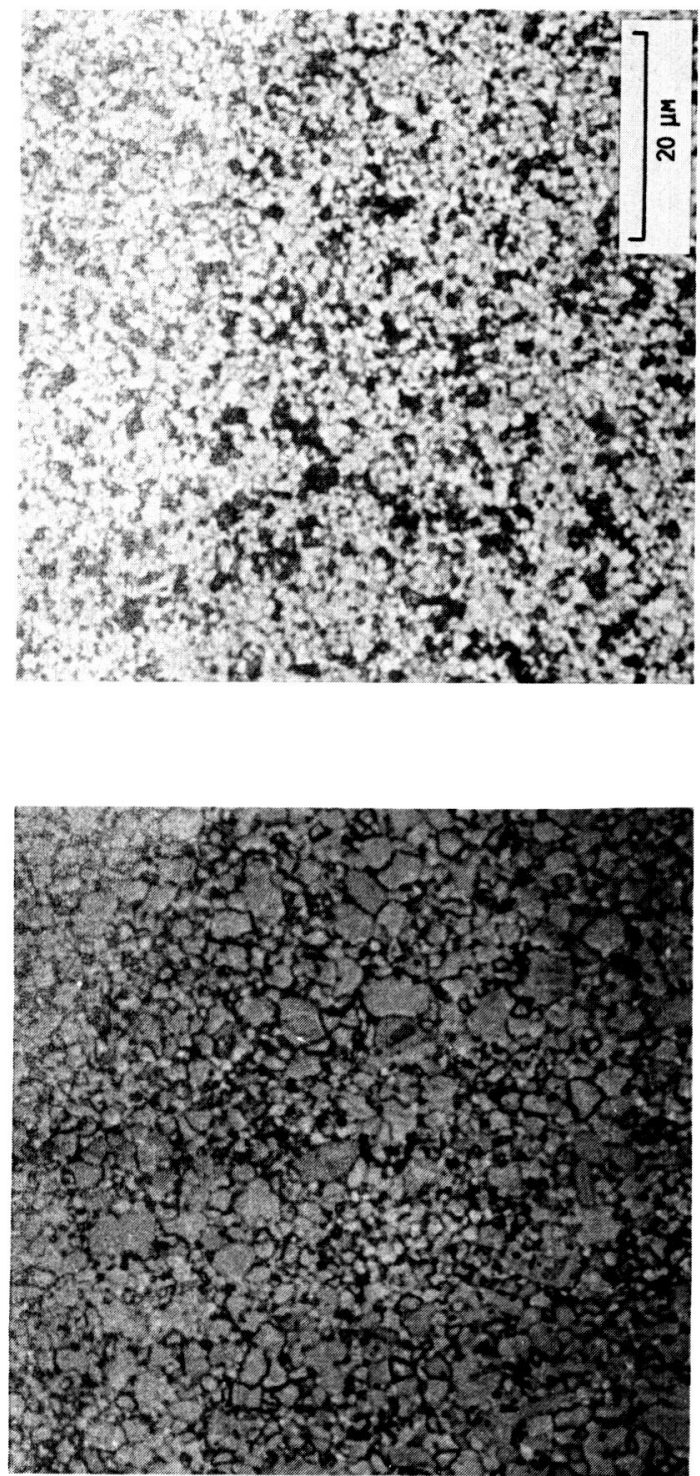

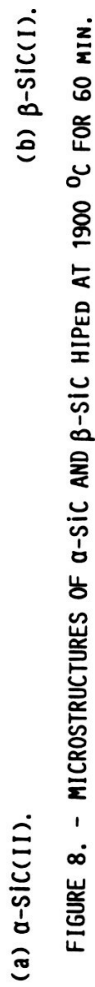

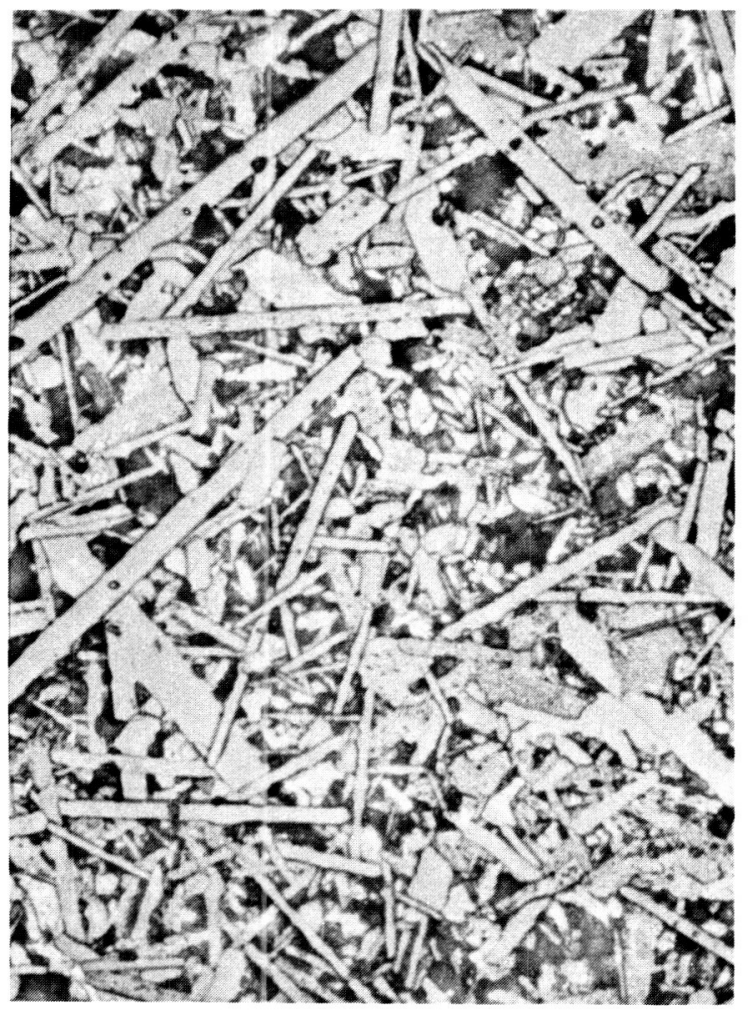

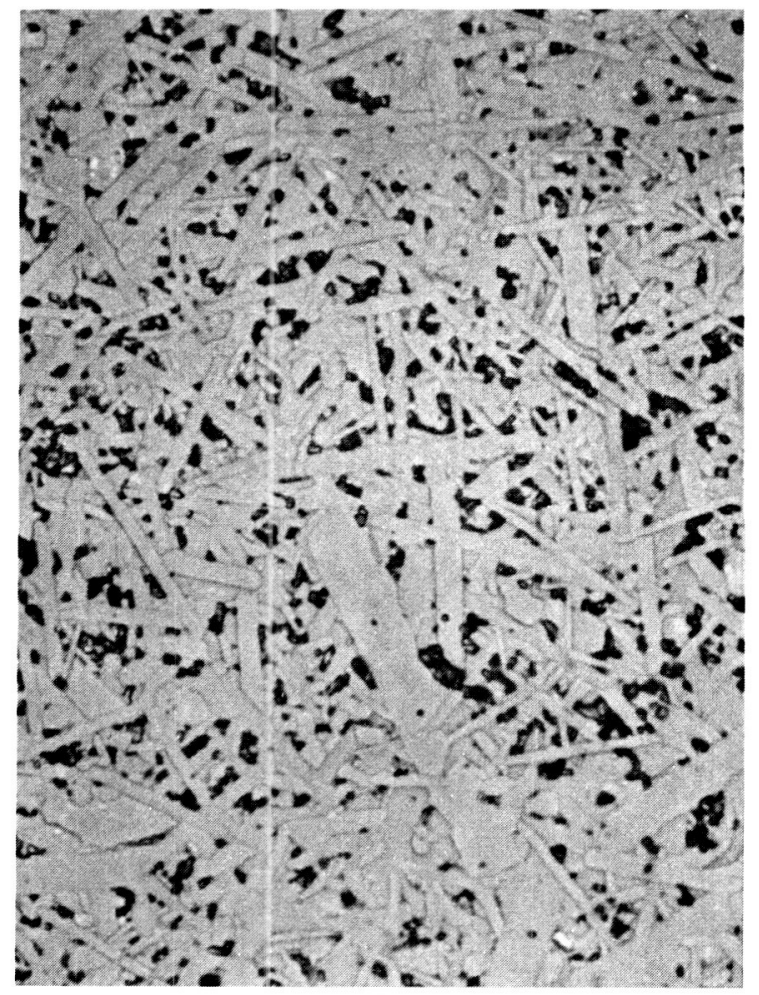

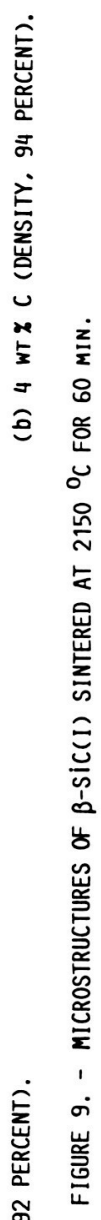




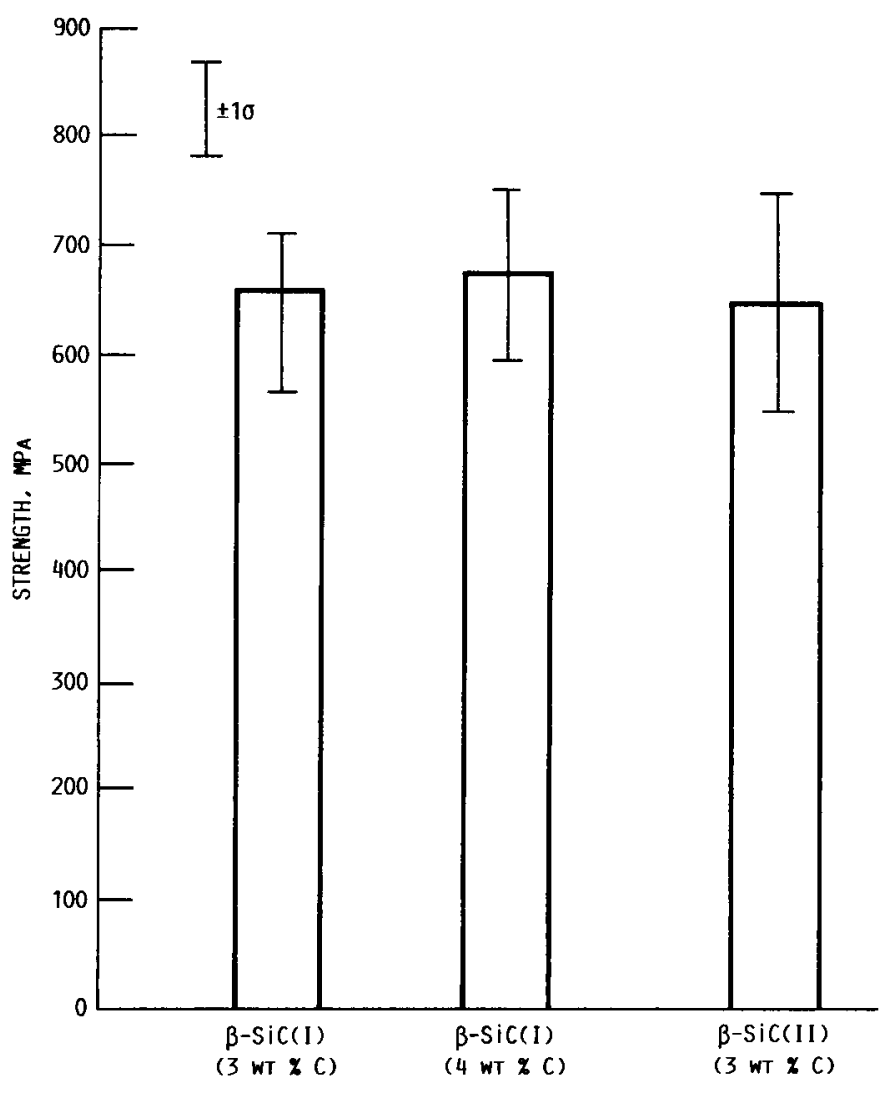

FIGURE 10 . - ROOM-TEMPERATURE FLEXURAL STRENGTH OF $\beta$-SIC HIPED AT $1900{ }^{\circ} \mathrm{C}$ FOR 60 MIN.

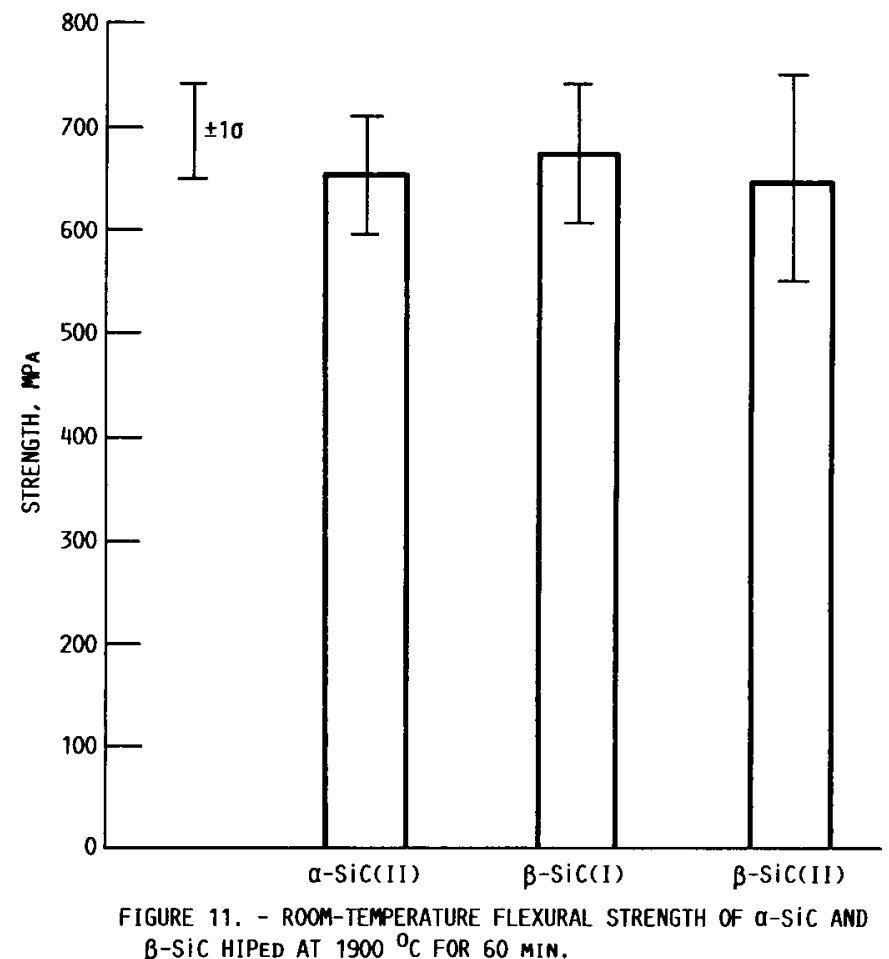



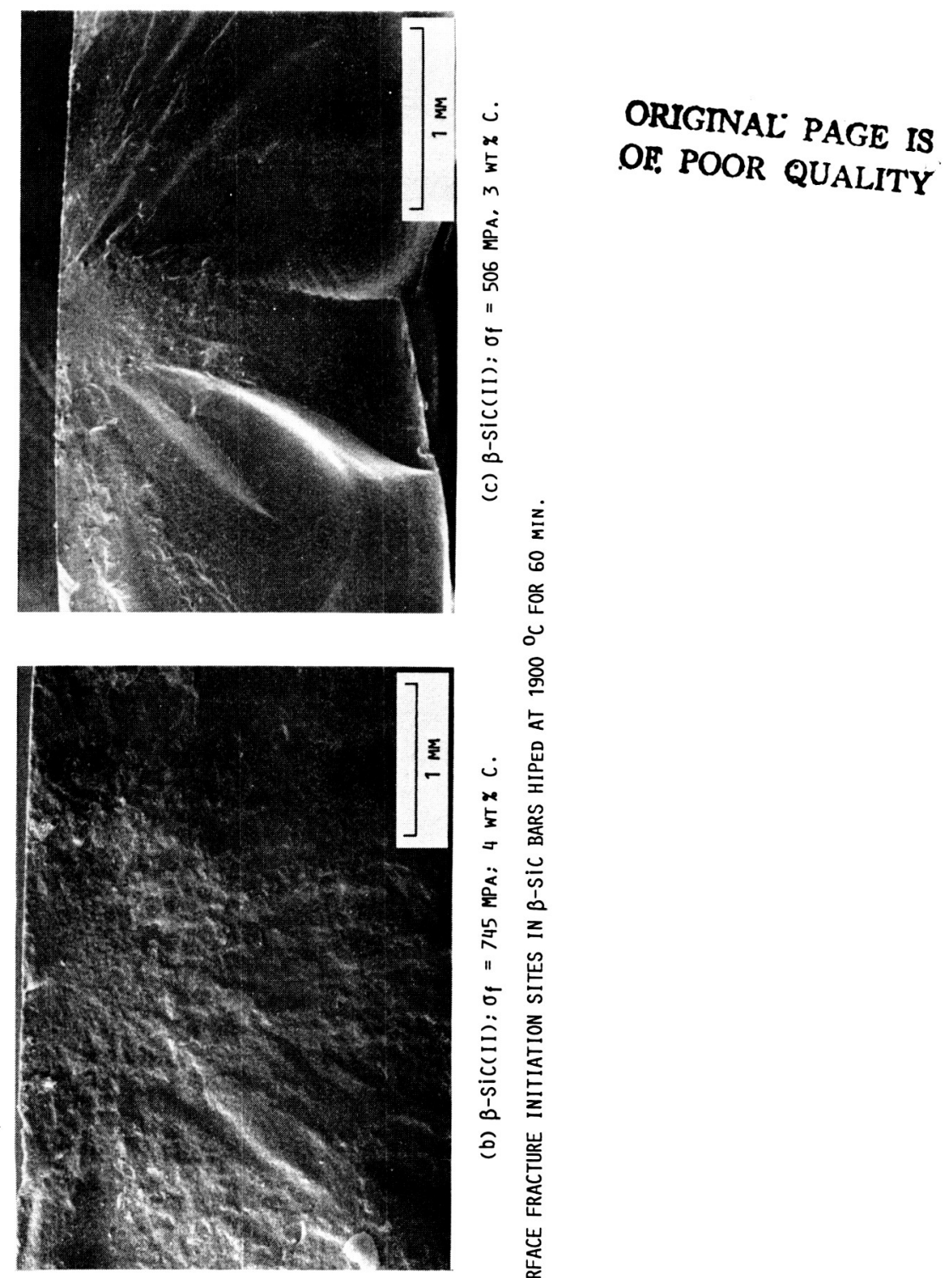

옹

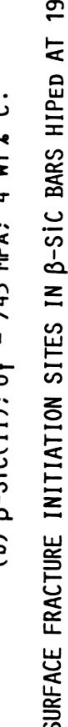
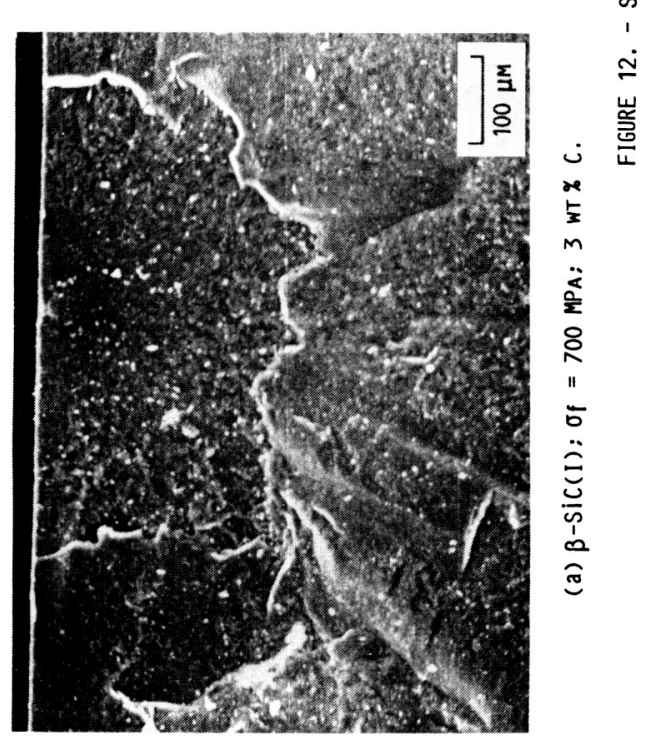


\begin{tabular}{|c|c|c|c|c|}
\hline \multicolumn{5}{|c|}{ Report Documentation Page } \\
\hline $\begin{array}{l}\text { 1. Report No. } \\
\text { NASA TM-101400 }\end{array}$ & \multicolumn{2}{|c|}{ 2. Government Accession No. } & \multicolumn{2}{|c|}{ 3. Recipient's Catalog No. } \\
\hline \multirow{2}{*}{\multicolumn{3}{|c|}{$\begin{array}{l}\text { 4. Title and Subtitle } \\
\text { High-Strength Silicon Carbides by Hot Isostatic Pressing }\end{array}$}} & \multicolumn{2}{|l|}{ 5. Report Date } \\
\hline & & & \multicolumn{2}{|c|}{ 6. Performing Organization Code } \\
\hline \multirow[t]{2}{*}{$\begin{array}{l}\text { 7. Author(s) } \\
\text { Sunil Dutta }\end{array}$} & & & \multicolumn{2}{|c|}{$\begin{array}{l}\text { 8. Performing Organization Report No. } \\
\text { E-4484 }\end{array}$} \\
\hline & & & \multicolumn{2}{|l|}{$\begin{array}{r}\text { 10. Work Unit No. } \\
505-63-1 \mathrm{~A}\end{array}$} \\
\hline \multirow{2}{*}{\multicolumn{3}{|c|}{$\begin{array}{l}\text { 9. Performing Organization Name and Address } \\
\text { National Aeronautics and Space Administration } \\
\text { Lewis Research Center } \\
\text { Cleveland, Ohio 44135-3191 }\end{array}$}} & \multicolumn{2}{|c|}{ 11. Contract or Grant No. } \\
\hline & & & \multicolumn{2}{|c|}{$\begin{array}{l}\text { 13. Type of Report and Period Covered } \\
\text { Technical Memorandum }\end{array}$} \\
\hline \multicolumn{3}{|c|}{$\begin{array}{l}\text { 12. Sponsoring Agency Name and Address } \\
\text { National Aeronautics and Space Administration } \\
\text { Washington, D.C. 20546-0001 }\end{array}$} & \multicolumn{2}{|c|}{ 14. Sponsoring Agency Code } \\
\hline \multicolumn{5}{|c|}{$\begin{array}{l}\text { Prepared for the Third International Symposium on Ceramic Materials and Components for Engines sponsored by } \\
\text { the American Ceramic Society, Las Vegas, Nevada, November 27-30, } 1988 \text {. }\end{array}$} \\
\hline \multicolumn{5}{|c|}{ 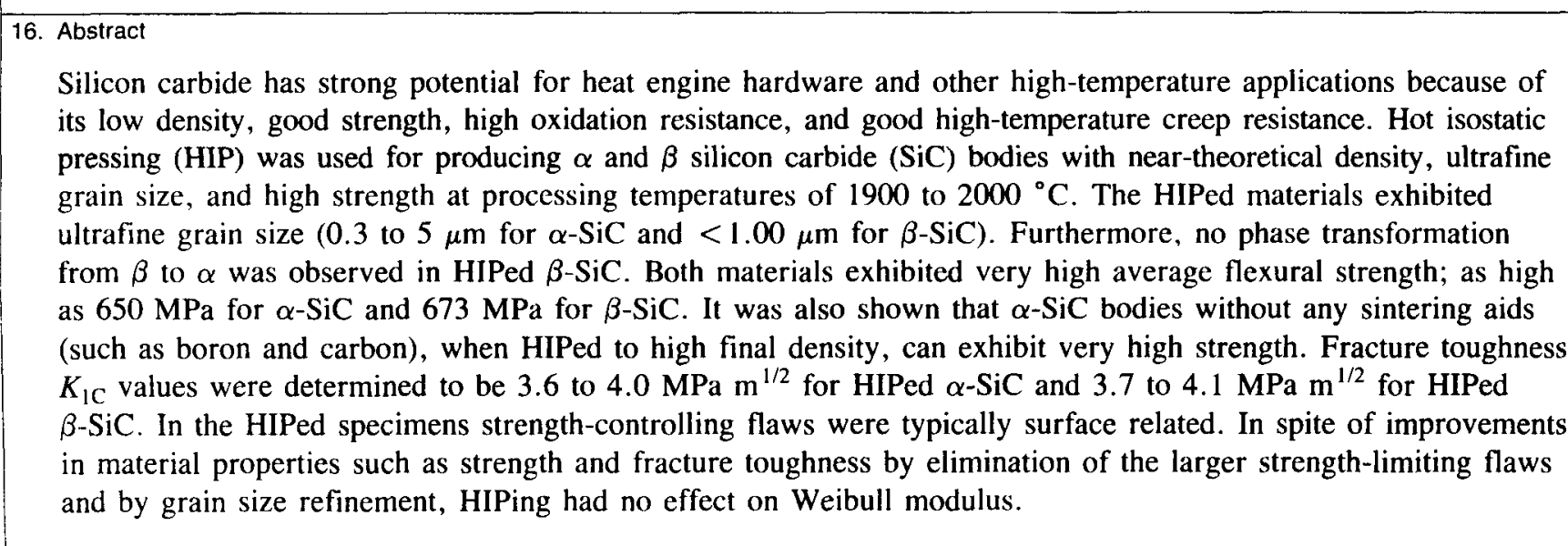 } \\
\hline $\begin{array}{l}\text { 17. Key Words (Suggested by Auth } \\
\text { Processing; Hot isostatic } \\
\text { Microstructure; Fracture }\end{array}$ & ngth; & $\begin{array}{r}\text { 18. Distribu } \\
\text { Uno } \\
\text { Sub }\end{array}$ & $\begin{array}{l}\text { nent } \\
\text { - Unlimited } \\
\text { gory } 27\end{array}$ & \\
\hline $\begin{array}{l}\text { 19. Security Classif. (of this report) } \\
\text { Unclassified }\end{array}$ & 20. Se & $\begin{array}{l}\text { this page) } \\
\text { assified }\end{array}$ & $\begin{array}{c}\text { 21. No of pages } \\
18\end{array}$ & $\begin{array}{r}\text { 22. Price* } \\
\mathrm{A} 03\end{array}$ \\
\hline
\end{tabular}

